PEOPLE: International Journal of Social Sciences

ISSN 2454-5899

Alice-Magdalena Bodoc, 2022

Volume 7 Issue 3, pp. 169-188

Received: 24 ${ }^{\text {th }}$ August 2021

Revised: 01 st December 2021, 12 th January 2022, 17 th January 2022

Accepted: 19 th January 2022

Date of Publication: 20 th January 2022

DOI- https://doi.org/10.20319/pijss.2022.73.169188

This paper can be cited as: Bodoc, A. M. (2022). Syntactic Dislocation Phenomena in The Adverbial Clauses of Romance Languages- A Comparative Perspective. PEOPLE: International Journal of Social Sciences, 7(3), 169-188.

This work is licensed under the Creative Commons Attribution-NonCommercial 4.0 International License. To view a copy of this license, visit http://creativecommons.org/licenses/by-nc/4.0/ or send a letter to Creative Commons, PO Box 1866, Mountain View, CA 94042, USA.

\title{
SYNTACTIC DISLOCATION PHENOMENA IN THE ADVERBIAL CLAUSES OF ROMANCE LANGUAGES - A COMPARATIVE PERSPECTIVE -
}

\author{
Alice-Magdalena Bodoc \\ PhD. Senior Lecturer, Department of Theoretical and Applied Linguistics, Faculty of Letters \\ Transilvania University, Brașov, Romania \\ alice_bodoc@unitbv.ro
}

\begin{abstract}
The present paper presents some important aspects concerning the syntactic configuration of Romanian, Italian, and French clausal adjuncts, as they appear in the articles from the presentday media. I have chosen two international magazines and three representative daily newspapers for each of the three languages. The elements investigated in this paper relate to the syntaxinformation structure interface, such as scrambling, interpolation, left dislocations, and these are going to be discussed, by comparison, for the complex sentences with temporal and causal adjuncts. Although there are authors arguing that French has a fixed word order (Manoliu, 2011, pp. 505-507, among others) or that "pro-drop languages" (Romanian and Italian) behave differently than "non-pro-drop" language (French) as concerns the relationship between
\end{abstract}


information structure and word order, they are partly contradicted by the results of this analysis which brings evidence that, at least from this point of view, they are very similar. In the end, I conclude that all three Romance varieties have word order preferences and modified configurations, and they share many linguistic features, although French is more restrictive.

\section{Keywords}

Adverbial Clauses, Information Structure, Word Order, Romance Languages

\section{Introduction}

Considering the actual state of the art of the international research in the area of Romance linguistics, and the growing interest in introducing Romanian data in these studies, the paper is going to enrich the (comparative) linguistics area, by the integrative approach that combines the instruments of various domains. The contribution of the paper to the field resides in the comparative perspective undertaken, focusing on the relationship between information structure (henceforth IS) and word order (henceforth WO) in Romance temporal and causal adjuncts. The innovative character of this article is given by the fact that it uses an original corpus, constructed by the author, and it aims at synchronizing the Romanian linguistic research with current developments at an international level, thus giving the researchers interested in Romance languages the opportunity to use Romanian data in their comparative studies.

\section{Research Issues}

The complex sentences under investigation can be defined, following Diessel (2019, p. 98), as "a biclausal construction consisting of a main clause and a subordinate clause in which the event designated by the subordinate clause specifies the circumstances under which the event of the main clause takes place". The following research questions are in focus:

- Is there cross-linguistic and language-internal variation inside the Romance languages family?

-What is the effect of IS on WO in Romanian, Italian, and French adjuncts?

- Is the 'pro-drop' feature a determining factor for the cross-linguistic variation at the syntax/information structure interface? 


\subsection{Objectives of the Paper}

This paper aims to provide a comprehensive descriptive account of the relationship between IS and WO in Romance temporal and causal adjuncts. My first objective is to quantify the degree of productivity of these linguistic phenomena in the three kindred languages through a corpus-based analysis. The second objective is to describe the syntactic configurations that Romanian, Italian, and French resort to, in order to fulfil various discourse roles. Finally, my third objective will be to put forward the assumption that all three languages behave similarly as concerns the syntax-information structure interface, although French has been usually interpreted as special, due to its word order restrictions.

\subsection{Corpus and Methodology}

To the best of my knowledge, there are no corpora available that would allow for a thorough comparative statistical analysis of word order in Romanian, French, and Italian. So, the first step was to build a Contemporary Romance corpus (ROAMED corpus). I found some international magazines and national newspapers published online during 2015-2019, and I extracted an equal number of words from each of these publications (around 530.000 words). After organizing the corpus, I searched for the CSs with temporal and causal adjuncts, I extracted manually all the contexts in which they appear, and I created a database according to the linguistic features that are going to be examined. A total number of $1697 \mathrm{CSs}$ were selected, and the following categories were organized: 464 CSs with Romanian temporal adjuncts (RTAs), 329 CSs with Italian temporal adjuncts (ITAs), and 305 CSs with French temporal adjuncts (FTAs). For the causal adjuncts, the numbers are 207, in Romanian (RCAs), 244, in Italian (ICAs), and 148 CSs in French (FCAs).

From a methodological point of view, the paper combines corpus analysis and comparative analysis, to get a deeper understanding of the impact of IS categories of Topic and Focus on WO of Romance adjunct clauses. The descriptive framework is modern, yet still fairly traditional, using not too technical apparatus, and different from the discourse analysis perspective.

\section{Basic concepts - Literature review}

It is generally accepted the idea that most of the Romance languages inherited the Latin syntactic configuration of the sentence, and also its relatively free word order (Klein, 2012, p. 99). This is the case of Romanian and Italian which allow (under the right circumstances) any ordering 
of the major constituents (Subject $-\mathrm{S}$, Verb $-\mathrm{V}$, Direct Object $-\mathrm{O}$ ), and even the case of French, although this language has more rigid restrictions. In all these languages, the common and dominant unmarked word order of the body of a declarative main clause is SVO (Dryer, 2005, p. 332; Pană Dindelegan \& Maiden, 2013, p. 494; Ledgeway, 2011, p. 408), and the grammatical subject corresponds to the topic.

In their study on Spanish, Italian, and French, Lahousse \& Lamiroy (2012) provide arguments to sustain the assumption that the "different word order patterns can be accounted for in terms of grammaticalization". According to their research, Spanish is the least grammaticalized, as it "has all types of word order except SOV (i.e., SVO, VOS, OSV, VSO and OVS), while Italian lacks SOV and VSO, and French lacks SOV, VSO and OVS", being the most grammaticalized language (Lahousse \& Lamiroy, 2012, p. 387). For Romanian, I gave examples for the six possible orders of a sentence, and I evaluated their acceptability from the point of view of a native speaker.
a. Fetele citesc cărți (SVO) girls-NOM read-3 PL:PRES
books-ACC
'The girls read books'
b. Citesc cărți fetele. (VOS)
c. Cărți fetele citesc. (OSV)
d. Fetele cărți citesc. (SOV)
e. Cărți citesc fetele. (OVS)
f. Citesc fetele cărți.
(VSO)

These examples prove that, compared to other kindred languages, Romanian is a free word order language, very similar to Spanish, allowing all the possible combinations, and less restrictive than Italian and French. "According to Zubizarreta (1998), Belletti \& Shlonsky (1995) and Sornicolà (1994), Italian does not allow VSO, and according to Renzi, Salvi \& Cardinaletti (2001, p. 142), OVS is used in a stile elevator o antico, that is, it sounds archaic or literary". "Modern French is even more restrictive, as only VOS, and marginally OSV, are allowed besides SVO" (Lahousse \& Lamiroy, 2012, p. 388).

Some linguists consider that the "relative word order freedom is a feature of null subject/pro-drop languages", such as Romanian, Spanish, and Italian (Pană Dindelegan \& Maiden, 2013, p. 494), while French lost the Latin pro-drop feature in the fourteenth century, as a result of the progressive fixation of the subject in preverbal position (the fixation of SVO) (Lahousse \& 
Lamiroy, 2012, p. 396). As a native speaker of Romanian, I know that not all orders from the examples under (1) are acceptable in all contexts, and that, besides this typological feature, there are many other factors that determine the marked/alternative word orders in Romance languages. Some of these factors belong to the IS and are going to be discussed later in this study.

\subsection{Information Structure}

It is very important to understand that the constituents are arranged in a sentence following certain rules for the speaker to send a proper message to its interlocutor, and thus, to serve discourse purposes. We usually place the already known information at the beginning of the sentence, while the new information is placed toward the end. From this point of view, “information structure can be defined as common ground management: speakers use certain linguistic forms to signal which aspects of the common ground are relevant at a given point in discourse and what operations are to be performed on the common ground" (Matić, van Gijn \& van Valin Jr., 2014, p. 2).

Cross-linguistically, there are different means of structuring the discourse information, and many concepts that researchers use in their studies to operate/describe the interplay between syntax and information structure. Given/New, Theme/Rheme, Topic/Comment, Topic/Focus are just a few of the distinctions taken into consideration, and, although it has received a variety of interpretations in the linguistic literature (Givón, 1979; Lambrecht, 1994; among others), the latter pair of notions - Topic and Focus - is the most relevant for my analysis, as it plays a major role in explaining the properties of Romance word order as a result of scrambling.

\subsubsection{Focus}

Defined in terms of given and new information, the concepts of topic and focus are quite easily to understand. The topic correlates to the given information (mentioned in the previous discourse $=$ the theme $)$, and the focus to the new information (not mentioned before $=$ the rheme).

\subsubsection{Topic}

The other important concept related to the IS of a sentence is topic, previously defined as the "given" information of discourse. Furthermore, there are linguists who consider that topic should be understood in terms of "aboutness", i.e., "that part of the sentence which we are talking about and which anchors the sentence to the common ground (Reinhart, 1982). In the case of normal SVO word order, the aboutness topic coincides with the subject of the clause and generally occurs to the left of the focus" (Winkler, 2012, p. 76). From this point of view, Lambrecht (1994) 
distinguishes two types of topics: "the pragmatic category 'topic' and the grammatical category 'topic expression'” (Lambrecht, 1994, p. 131).

\subsection{Syntactic dislocations phenomena}

The general assumption of this article is that non-SVO syntactic configurations from temporal and causal adjuncts appear in special constructions of the journalistic ROAMED corpus, in order to indicate a particular information status. These special constructions involve dislocations, interpolations, and/or scrambling.

\subsubsection{Dislocations}

Dislocation is the term I use in this article whenever a constituent is 'detached' from its sentential core position and moved (for specific reasons) to another place, a nonspecific one, from the left or the right periphery of the clause. The assumed interest of this article is to analyze dislocations as related to the representation of IS, and this means that I will not try to find answers for the various questions that researchers (Jackendoff, 1972; Culicover \& Rochemont, 1983; Rochemont, 1986; Vallduví, 1992; Lambrecht, 1994; Bailyn, 1995; Junghanns \& Zybatow, 1997; Miyagawa, 1997; Erteschik-Shir, 1997; Zubizarreta, 1998) have addressed in their studies. According to Klein (2012, p. 104), the main types of dislocations are the following (with the corresponding examples from French):

(a) left and right dislocations:

(2) La pomme, elle est rouge. 'The apple, it is red.'

(3) Elle est rouge, la pomme. 'It is red, the apple.'

(b) cleft constructions :

(4) C'est la pomme qui est rouge. 'It is the apple that is red.'

(c) Presentationals which come in two variants - with il y a or with avoir:

(5) Il y a une jeune fille qui m'a téléfoné. 'A girl called me.'

We shall see in the following sections that all these types of dislocations occur in Italian and Romanian as well, the most frequent being the (clitic) left dislocation, associated with the function of Topic or Focus. As it results from the examples, the two indicators of left dislocation are sentence-initial position and the occurrence of a resumptive pronoun (elle or $l$ ').

\section{Clitic Left Dislocation (CLLD)}

The phenomenon called clitic left dislocation by Cinque 1990 appears when the direct and indirect objects realized as determined noun phrases (NPs) or as pronouns are placed in the initial 
position, in the obligatory presence of clitic resumption (Pană Dindelegan \& Maiden, 2013, p. 497).

$$
\begin{aligned}
& \text { (îi) scriu băiatului / Băiatului } \hat{\imath} i \quad \text { scriu } \\
& \text { CL.DAT.3SG (I)write boy.DEF.DAT boy.DEF.DAT CL.DAT.3SG (I)write } \\
& \text { 'I write to the boy' 'It is the boy to whom I write' } \\
& \text { (apud Pană Dindelegan \& Maiden, 2013, p. 497). }
\end{aligned}
$$

Haegeman (2012) investigates very carefully the Romance CLLD as a way of expressing the topic-comment articulation of this sentence. Her study is especially important for my paper because, on the one hand, it provides undeniable arguments to support the internal IS of adverbial clauses (with focus on the left periphery), and, on the other hand, it provides many examples from Romance languages, such as French, Italian, Spanish, and Catalan. Unfortunately, it lacks Romanian data, and, from this point of view, the present research fills a gap in the comparative Romance studies.

\subsubsection{Interpolations}

Another way of affecting the SVO configuration, a special type of dislocation, is called interpolation. The term was first used by Winthrop Holt Chénery (apud Poole, 2007) to refer to dislocations that imply the pronominal clitic and the verb (Nicolae, 2015, p. 13). Some linguists use the terms interpolation and scrambling in free variation (see Nicolae, 2015, p. 118 for a detailed presentation), but, for this paper, I make a clear distinction between the two concepts (although I do not deny their similarities). From my point of view, interpolation is a pragmatic strategy that directly affects the verb, and it can be illustrated by the following configurations: $[$ Aux $-\mathbf{A d v}-\mathrm{V}]$ and $[\mathrm{Neg}-\mathrm{Cl}-\mathbf{A d v}-\mathrm{V}]$. In these patterns, the verbal nucleus of a sentence (containing functional elements, such as the negation or the auxiliary + the lexical verb) is interrupted by one interpolated constituent.

$$
\text { Andrei s-a cam plictisit la petrecere. [Aux - Adv - V] }
$$

'Andrei got rather bored at the party'

\subsubsection{Scrambling}

As noted in a previous section of this paper, scrambling is a stylistically-driven process used by the speaker to derive the alternative orders (Bailyn, 2003, p. 157). According to Routledge Dictionary of Language and Linguistics (Bussmann, 2006), scrambling is "a term coined by J. R. Ross (1967) to describe transformations which generate surface structures with varying word 
orders from a basic structure. Scrambling also refers to the relationships between the permuted parts of the sentence (permutation)"'. In this paper, I use the term scrambling with an extended meaning for all the syntactic configurations in which a free word order permutation occurs, and the $(\mathrm{O}) \mathrm{VS}(\mathrm{O})$ scrambled pattern that is going to be investigated here is called stylistic inversion (SI) (Haegeman, 2012, p. 158). So, if we accept the first clause (8 a) as the basic order in Romanian, then scrambling has occurred in clauses $b-f$.

(8) a. Fetele citesc cărți (SVO)

'The girls read books'

b. Citesc cărți fetele. (VOS)

c. Cărți fetele citesc. (OSV)

d. Fetele cărți citesc. (SOV)

e. Cărți citesc fetele. (OVS)

f. Citesc fetele cărți. (VSO)

\section{IS and WO in The Adjunct Clauses of Romance Languages - ROAMED Corpus Analysis}

Romanian, Italian and French has been argued to be configurational languages (Kiss, 1995; Baker, 2001; Pană Dindelegan \& Maiden, 2013, p. 494), in the sense that they have a canonical SVO word order. Still, there are many factors that affect the prototypical order of the constituents, and this results in discourse-oriented flexibility of surface configurations.

\subsection{Quantitative Results}

In the selected ROAMED corpus, I found and extracted 464 CSs with Romanian temporal adjuncts (RTAs), 329 CSs with Italian temporal adjuncts (ITAs), and 305 CSs with French temporal adjuncts (FTAs). For the causal adjuncts, the numbers are: 207, in Romanian (RCAs), 244, in Italian (ICAs), and 148 CSs in French (FCAs). All the previously described linguistic phenomena were searched for in these sentences, and the quantitative results of the analysis are summarized in the next two Figures: 


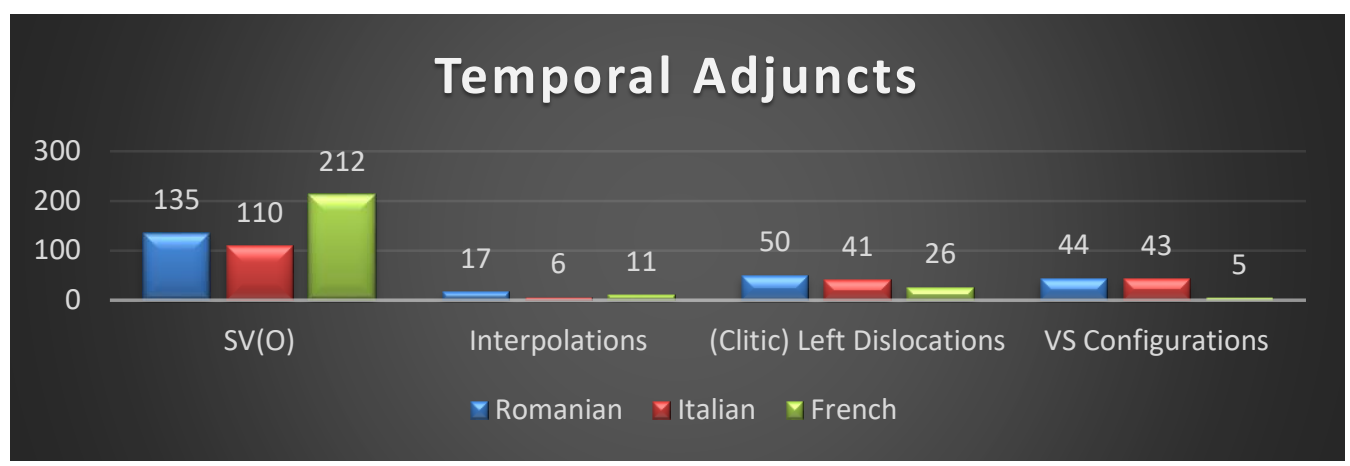

Figure 1: Distribution of the investigated phenomena in the ROAMED corpus

(Source: Self)

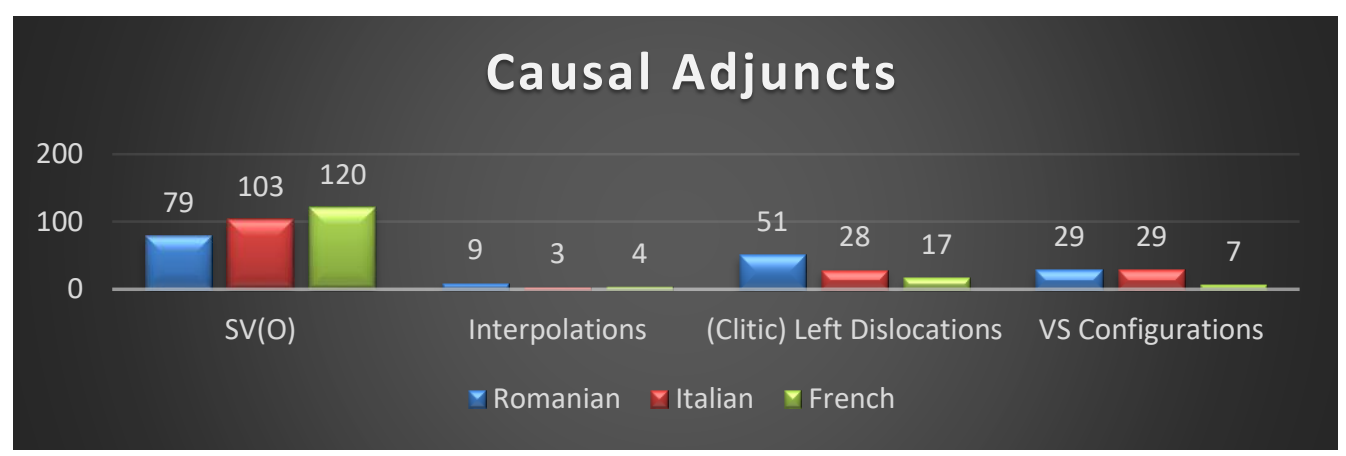

Figure 2: Distribution of the investigated phenomena in the ROAMED corpus

(Source: Self)

As concerns the temporal adjuncts, the Figure illustrates the fact that most of the extracted subordinate clauses follow the canonical $\mathrm{SV}(\mathrm{O})$ word order of the constituents, but there are also many structures in which the prototypical order is slightly affected or even highly modified. It should be noted that not all the extracted adjuncts were registered in this Figure, as I decided to leave aside the temporal or causal adjuncts in which the connector is followed by an infinitive and the adjuncts with the non-overt subject. This feature, also known as 'null pronominal subject' is specific to the so-called 'pro-drop languages, such as Romanian and Italian. Unlike FTAs, in which subject realization is obligatory (as French is not a pro-drop language), almost a half of the extracted RTAs, and many ITAs have this type of subject or have no subject at all. Among the Romance languages, Romanian belongs to the same group as Italian, Spanish, and Portuguese, but it is different from standard French, where we can find an expletive clitic il (Renzi \& Andreose, 2003, p. 217; Reinheimer \& Tasmowski, 2005, pp. 105-106; Metzeltin, 2011, p. 84) or a generic pronoun on in subject position (Pană Dindelegan \& Maiden, 2013, p. 108). Figures 1 and 2 indicate that, on the one hand, the $\mathrm{SV}(\mathrm{O})$ configuration is prototypical for the temporal and causal adjuncts 
from all three investigated languages, and, on the other hand, they behave similarly as far as the linguistic phenomena affecting WO are concerned.

\subsection{Discussions}

From a qualitative point of view, the results of the ROAMED corpus analysis are revealing for the morphosyntactic flexibility and complexity of Romance languages. Although there are authors who argue that French has a fixed word order (Manoliu, 2011, pp. 505-507, among others) or that the "pro-drop languages" (Romanian and Italian) behave differently than the "non-prodrop" French language as concerns the relationship between IS and WO, they are partly contradicted by the results of the quantitative analysis.

\subsubsection{Left Dislocations in ROAMED Corpus}

As results from Figures 1, and 2 above, left dislocations to occur in 213 CSs extracted from ROAMED corpus: 117 in CSs with TAs, and 96 in CSs with CAs. This means that left-dislocated elements in this corpus occur in adjunct clauses covering about $12 \%$ of the total number, which seems quite a high percentage. The distribution for each of the three investigated languages is illustrated in the Figure 3.

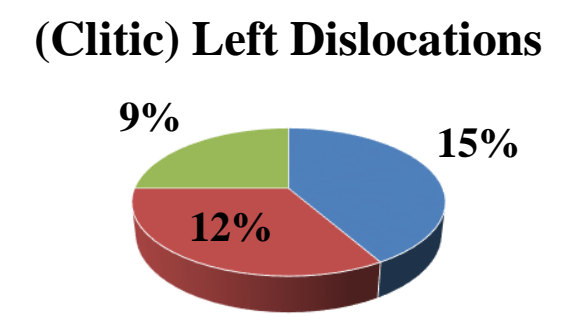

- Romanian - Italian $\backsim$ French

Figure 3: The distribution of (clitic) left dislocations in the ROAMED corpus $\backslash$ (Source: Self)

Although linguists such as Emonds (1970), and Ogle (1981) claimed that left dislocation is not allowed within subordinate clauses in English, they were seriously contradicted by others (Hooper \& Thompson, 1973; Gundel, 1975; Hirschbühler, 1997; Shaer, 2009), who claimed that some types of subordinate clauses do allow left dislocation (van Putten, 2014, p.71). In this section, I demonstrate that left dislocation in general, and clitic left dislocation in particular, do occur within Romance subordinate clauses. This evidence comes from all three languages, with the 
annotation that "left dislocation is an extremely frequent topicalization mechanism in Romanian, in which certain structures are grammaticalized” (Pană Dindelegan \& Maiden, 2013, p. 496).

The dislocated/moved 'element' can be:

\section{An Adverb or And Adverbial Phrase (AdvP)}

(9) Paris a été témoin de belles dispersions qui risquent d'être de plus en plus rares car aujourd'hui personne n'est apte à rassembler de pareils trésors. (LF, 2018) 'Paris has witnessed beautiful dispersions which are likely to be increasingly rare because today no one can collect such treasures'

\section{$>\underline{\text { A Modal Adverbial }}$}

(10) Ancora, 151 milioni verranno erogati per le pensioni di ex-Dipendenti mentre, interessante, saranno 22 i milioni a favore dei Gruppi Parlamentari. (IFQ, 2018) 'Still, 151 million will be paid for the pensions of former employees while, interestingly, 22 million will be paid to parliamentary groups'

\section{$>\underline{\text { A Prepositional Phrase (PrepP) }}$}

(11) Este interesant de descoperit cum au rupt cele două țări relațiile diplomatice în anul 1941, după ce în 1921 ele au fost membre fondatoare ale alianței politicomilitare. (A, 2015)

'It is interesting to discover how the two countries broke off diplomatic relations in 1941, after in 1921 they were founding members of the politico-military alliance'

We notice that the dislocated 'element' is placed in the initial position of the adjunct clause, i.e., the first position after the temporal or causal connector, and preceding the realized subject. All these examples illustrate the dislocation of elements that were not the arguments of the verbs, and that is usually placed after the verbal core (SVO), but there are also cases in which the detached element is an argument, and, in these cases, there has to be an element (a clitic) in the remainder of the sentence "cross-referencing the left-dislocated one" (van Putten, 2014, p. 75). This type of dislocation is called Clitic Left Dislocation, abbreviated CLLD.

CLLD are also available in Romanian, Italian, and French temporal and causal adjuncts, and the argument position taken by the detached element (and also by the resumptive clitic) is that of a Direct Object.

(12) Omul ăsta, de când l-a eliminat "statul paralel”, e ...ați ghicit, șomeeeer! (EZ, 2018) 
"This man, ever since the "parallel state" eliminated him, you guessed it!, he is unemployed'

(13) Une explication soutenue par l'auteure de la cartocrise lorsque nous l'avions interrogée (L, 2015)

'An explanation supported by the author of the car to rise when we questioned her

All these examples allow us to identify a set of formal properties of the Romance adjuncts with left dislocations:

- the dislocated elements can be either arguments, or non-arguments of the verb; if it is an argument, then it must leave a trace (a co-referential clitic) in the remaining sentence;

- the dislocation can be interpreted as a strategy for marking the Topic or the Focus of a sentence, and, in this position, the dislocated element can set the spatial or temporal frame of the event;

- dislocations of the non-argument elements (adverbs or PrepP functioning as situative adjuncts) "are syntactically optional: when omitted, the remainder - the 'core' of the clause - is still a grammatical sentence. So, their use reflects a free decision on the part of the speaker as to how much information is provided about the NP referent or whatever else is described by the dislocation" (Klein, 2012, p. 104).

- $\quad$ sometimes, but not necessarily, an intonation break occurs (a pause, marked by a comma) between the left-dislocated element and the remainder of the utterance.

\subsubsection{Interpolation}

It is a very interesting linguistic phenomenon, although not very productive in the investigated languages (as Figures 1 and 2 show). There were identified 26 adjuncts with interpolations in Romanian, 15 adjuncts in French, and only 9 contexts in Italian, which seems to be a little more restrictive as concerns the insertion of different elements into the verbal complex. Fortement, vraiment, bien, partiellement, brutalement, infiniment, surtout are the French adverbs found in the interpolated structures, besides the form from the example (15). Still, the results contradicted my intuition in a certain way, and this can be explained - in my opinion - by the linguistic ‘flexibility' of Romanian.

The patterns with interpolated elements are the following:

\section{$[\mathrm{Neg}-(\mathrm{Aux})-\underline{\mathbf{A d v}}-\mathrm{V}]$}

(14) Iar când nu mai ești la vârsta adolescenței, parcă este și mai rău! (F, 2017) 
'And when you're not anymore in your teens, it's even worse'

$[\mathbf{A u x}-\underline{\mathbf{A d v}}-\mathbf{V}]$

(15) Quand on a bien dormi, on affronte la journée d'une meilleure façon. (E, 2017)

'When you've slept well, you face the day in a better way'

$[\mathrm{Neg}-\underline{\mathrm{Cl}}-\mathrm{V}]$

(16) Lui è andato via perché io non lo volevo più. (IG, 2018)

'He left because I didn't want him anymore'

Unlike in French, scrambling is less restricted in Romanian and Italian, making it possible to create numerous word order configurations. The VS type accounts for as much as 10,8 per cent of temporal and causal adjuncts in Romanian, $12,5 \%$ in Italian, and only 2,6 \% in French.
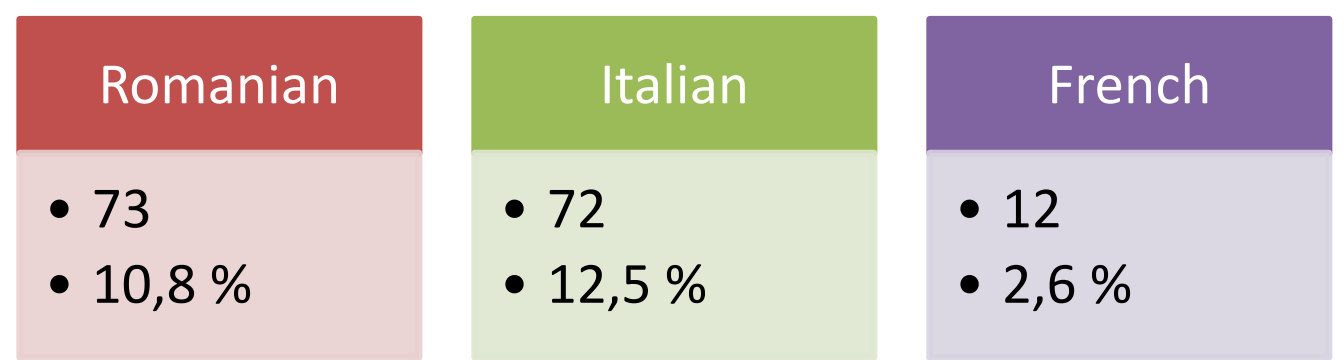

Figure 4: The distribution of scrambling in the ROAMED corpus

(Source: Self)

Scrambled clauses can have the following configurations:

\section{$\mathbf{O}(\mathrm{S}) \mathrm{V}$}

(17) Quando ti cura potrebbe farti anche male, ma sai che è per il tuo bene. (IG, 2019) 'When it cures you it might hurt you, but you know it's for your own good'

\section{SOV}

(18) Non è finita fino a quando M.L. lo indossa. (E, 2017)

'It's not over until M.L. wears it'

\section{VS}

(19) Les risques de famine ne sont pas écartés, alors que commence la période d'attente de la nouvelle récolte. (LM, 2019)

'The risks of famine have not been ruled out as the waiting period for the new harvest begins'

This last pattern received much attention in the literature on Romance word order, as it is the most interesting, and provoking. Haegeman (2012, p. 158) uses the term 'stylistic inversion' 
(SI) for this type of construction in which the subject is postposed and considers this to be an "additional evidence that temporal adverbial clauses have a left periphery". Other researchers name it 'free inversion' and consider this phenomenon specific to the pro-drop languages, such as Spanish and Italian, while absent in French. This assumption was rejected by Lahousse \& Lamiroy (2012), who argue that such a "radical opposition between Romance languages does not hold, or at least be fine-tuned" (2012, p. 388). I subscribe to their opinion, and I bring arguments that the VS configurations from Romanian, Italian, and French are licensed by specific/additional factors (syntactic and/or pragmatic).

A very relevant factor is the fronting of a spatial or temporal adjunct (adverb or PP):

(20) Le doux sillage qui flotte dans les airs se pare de nostalgie, car déjà vient le temps du bilan. (E, 2019)

'The gentle wake that floats in the air is adorned with nostalgia, because the time has already come to take stock'

(21) ...asta pentru că în terapia florală se consideră că rădăcina bolii se află la nivel psiho-emoțional și spiritual. (E, 2016)

'This is because in floral therapy it is considered that the root of the disease is at the psycho-emotional and spiritual level'

Another specific licensing factor is the presence of one or more explicit indications of the focal interpretation of the subject (Lahousse, 2010, p. 6), such as the fronting of negation:

(22) Mănânci pește de cel puțin două ori pe săptămână? Dacă răspunsul este nu, atunci ar fi bine să încerci să-ți ajustezi un pic meniul. Iar asta, nu pentru că-i la modă să mănânci pește, ci pentru că acest aliment e cu adevărat sănătos. (F, 2015)

'Do you eat fish at least twice a week? If the answer is no, then you should try to adjust your menu a bit. And that's not because it's fashionable to eat fish, but because this food is healthy'

\subsection{Concluding Remarks}

In this paper I have shown that all these linguistic phenomena viewed as specific to the main clauses, such as interpolation, (clitic) left dislocation or scrambling, also appear in the temporal and causal subordinate clauses from Romanian, Italian, and French, proving that they also have a strong relationship between IS and WO. We have seen that the canonical SVO order 
of all three languages can be affected by these 'processes', although French has more restrictions from this point of view. Left dislocation and scrambling are usually caused by the information structure of the context (topic and focus) and they obey several structural and discourse constraints (specific licensing factors). More research is needed to determine the connections between these linguistic phenomena (for instance, the connection between CLLD and the VS configuration) and the mechanisms that determine all these 'special syntactic configurations'. It also remains to be seen whether all the clausal adjuncts exhibit the same behaviour, i.e., they allow dislocations, scrambling and interpolation. Diachronic comparative studies are very significant too because these are phenomena attested in the old or medieval stages of Romance languages' evolution.

All in all, the results presented in this paper bring evidence for the complexity of the Romance varieties and represent a more refined understanding of word order variation from the complex sentences with temporal and causal adjuncts. Romanian, Italian, and French are sister languages that share many typological features, and this aspect confirms the importance of comparative studies.

\section{Acknowledgement}

This work was supported by a grant from the Romanian Ministry of Education and Research, CNCS - UEFISCDI, project number PN-III-P1-1.1-PD-2019-0052, within PNCDI III.

\section{ROAMED CORPUS}

\section{(available at https://roamed.unitbv.ro)}

\section{Italian}

newspapers:

1. Il Fato Quotidiano (IFQ 2015-2019) - https://www.ilfattoquotidiano.it/

2. Il Giornale (IG 2015-2019) - https://www.ilgiornale.it/

3. Il Foglio (IF 2015-2019) - https://www.ilfoglio.it/ magazines:

1. Elle (E 2015-2019) - https://www.elle.com/it/

2. Una Donna (UD 2015-2019) - https://www.unadonna.it/

\section{French}

\section{newspapers:}

1. Le Monde (LM 2015-2019) - https://www.lemonde.fr/ 
2. Le Figaro (LF 2015-2019) - https://www.lefigaro.fr/

3. Liberation (L 2015-2019) - https://www.liberation.fr/

magazines:

1. Elle (E 2015-2019) - https://www.elle.fr/

2. Femme Actuelle (FA 2015-2019) - https://www.femmeactuelle.fr/

\section{Romanian}

$>$ newspapers:

1. Adevărul (A 2015-2019) - https://adevarul.ro/

2. Evenimentul Zilei (EZ 2015-2019) - https://evZ.ro/

3. Jurnalul Naţional (JN 2015-2019) - https://jurnalul.ro/ magazines:

1. Elle (E 2015-2019) - https://www.elle.ro/

2. Femeia (F 2015-2019) - https://www.femeia.ro/

\section{REFERENCES}

Bailyn, J. F. (1995). A configurational approach to Russian "free" word order. Ph.D. thesis, New York: Cornell University.

Bailyn, J. F. (2003). Does Russian scrambling exist? S. Karimi (Eds), Word Order and Scrambling (pp. 156-176). Berlin: Blackwell Publishing. https://doi.org/10.1002/9780470758403.ch7

Baker, M. C. (2001). The Natures of Nonconfigurationality. M. Baltin \& C. Collins (Eds.), The Handbook of Contemporary Syntactic Theory (pp. 407-438). Oxford: Blackwell Publishers.https://doi.org/10.1038/35071216 https://doi.org/10.1038/35077122 https://doi.org/10.1038/35084172 https://doi.org/10.1038/35055524 https://doi.org/10.1038/35098178 https://doi.org/10.1038/35081151 https://doi.org/10.1038/35104729

Belletti, A., \& Schlonsky, U. (1995). The order of verbal complements: A comparative study. Natural Language and Linguistic Theory, 13, 489-526. https://doi.org/10.1007 /BF00992739. https://doi.org/10.1007/BF00992739 
Bussmann, H. (1996). Routledge Dictionary of Language and Linguistics. [Translated and edited by G. P. Trauth \& K. Kazzazi]. London: New York Routledge.

Chafe, W. (1994). Discourse, Consciousness and Time. Chicago: Chicago University Press.

Cinque, G. (1990). Types of A' Dependencies. Cambridge, Massachusetts, London, England: MIT Press.

Culicover, P. W., \& Rochemont, M. (1983). Stress and focus in English. Language, 59, 123165. https://doi.org/10.2307/414063

Diessel, H. (2019). Preposed adverbial clauses: Functional adaptation and diachronic inheritance. K. Schmidtke-Bode, N. Levshina, S. M. Michaelis, \& I. A. Seržant, (Eds.), Explanation in typology: Diachronic sources, functional motivations and the nature of the evidence (pp. 97-122). Berlin: Language Science Press.

Dryer, M. S. (2005). Order of Subject, Object, and Verb. M. Haspelmath, M. S. Dryer, D. Gil, \& B. Comrie (Eds.), The World Atlas of Language Structures (pp. 330-333). Oxford: Oxford University Press.

Emonds, J. E. (1970). Root and Structure-Preserving Transformations. Ph.D. dissertation Cambridge, Massachusetts, London, England: MIT.

Erteschik-Shir, N. (1997). The Dynamics of Focus Structure. Cambridge: Cambridge University Press. https://doi.org/10.1017/CBO9780511519949

Firbas, I. (1992). Functional Sentence Perspective in Written and Spoken Communication. Cambridge: Cambridge University Press. https://doi.org/10.1017/CBO9780511597817

Givón, T. (1979). On Understanding Grammar. New York: Academic Press. https://doi.org/10.1016/B978-0-12-285451-4.50010-2 https://doi.org/10.1016/B978-0-12-285451-4.50007-2 https://doi.org/10.1016/B978-0-12-285451-4.50012-6 https://doi.org/10.1016/B978-0-12-285451-4.50014-X https://doi.org/10.1016/B978-0-12-285451-4.50013-8 https://doi.org/10.1016/B978-0-12-285451-4.50011-4 https://doi.org/10.1016/B978-0-12-285451-4.50008-4

Gundel, J. K. (1975). Left dislocation and the role of topic-comment structure in linguistic theory. Ohio State University Working Papers in Linguistics, 18, 72-131. 
Haegeman, L. (2012). Adverbial Clauses, Main Clause Phenomena, and Composition of the Left Periphery. Oxford: Oxford University Press. https://doi.org/10.1093/acprof:oso/9780199858774.001.0001

Hirschbühler, P. (1997). On the source of lefthand NPs in French. E. Anagnostopoulou, H. van Riemsdijk \& F. Zwarts (Eds.), Materials on Left Dislocation [Linguistik Aktuell/Linguistics Today 14] (pp. 55-66). Amsterdam: John Benjamins. https://doi.org/10.1075/la.14.06hir

Hooper, J. B., \& Thompson, S. A. (1973). On the applicability of root transformations. Linguistic Inquiry, 4 (4), 465-497.

Jackendoff, R. (1972). Semantic Interpretation in Generative Grammar. Cambridge, MA: Massachusetts Institute of Technology Press.

Junghanns, U., \& Zybatow, G. (1997). Syntax and information structure of Russian clauses. W. Browne (Ed.), Annual Workshop on Formal Approaches to Slavic Linguistics (pp. 289319) [The Cornell Meeting 1995]. Michigan: Michigan Slavic Publications.

Karimi, S. (Ed.). 2003. Word Order and Scrambling. Berlin: Blackwell Publishing Ltd https://doi.org/10.1002/9780470758403

Kiss, K. É. (1995). Introduction. K. É. Kiss (Ed.), Discourse Configurational Languages (pp. 327). New York/Oxford: Oxford University Press.

Klein, W. (2012). The information structure of French. M. Krifka, \& R. Musan, The Expression of Information Structure (pp. 95-127). Berlin/Boston: De Gruyter Mouton.

Krifka, M. (1999). Additive particles under stress. D. Strolovitch \& A. Lawson (Eds.), Proceedings of Semantics and Linguistic Theory 8 (pp. 111-128). Cornell University: Chicago Linguistic Society Publications. https://doi.org/10.3765/salt.v8i0.2799

Lahousse, K., \& Lamiroy, B. (2012). Word Order in French, Spanish and Italian: a. grammaticalization account. Folia Linguistica, 46 (2), 387-415. https://doi.org/10.1515/flin.2012.014

Lambrecht, K. (1994). Information structure and sentence form: Topic, focus, and the mental representations of discourse referents. Cambridge: Cambridge University Press. https://doi.org/10.1017/CBO9780511620607

Ledgeway, A. (2011). Syntactic and Morphosyntactic Typology and Change. M. Maiden, J. C. Smith, and A. Ledgeway (Eds.) (2011). The Cambridge History of Romance Languages. 
I. Structures (pp. 382-471). Cambridge/New York: Cambridge University Press. https://doi.org/10.1017/CHOL9780521800723.010

Manoliu, M. M. (2011). Pragmatic and Discourse Changes. M. Maiden, J. Ch. Smith, \& A. Ledgeway (Eds.), The Cambridge History of Romance Languages. I. Structures (pp. 472531). Cambridge/New York: Cambridge University Press. https://doi.org/10.1017/CHOL9780521800723.011

Matić, D., van Gijn, R., \& van Valin, Jr., R. D. (2014). Information structure and reference tracking in complex sentences: An overview. R. van Gijn, J. Hammond, D. Matić, S. van Putten \& A. V. Galucio (Eds.), Information Structure and Reference Tracking in Complex Sentences (1-44). Amsterdam/Philadelphia: John Benjamins Publishing Company. https://doi.org/10.1075/tsl.105.01mat https://doi.org/10.1075/tsl.105.05mat

Metzeltin, M. (2011). Gramatica explicativă a limbilor romanice. Sintaxă şi semantică. Iaşi: 'Alexandru Ioan Cuza' University Publishing House.

Miyagawa, S. (1997). Against optional scrambling. Linguistic Inquiry, 28 (1), 1-25.

Nicolae, A. (2015). Ordinea constituenților în limba română: o perspectivă diacronică. Structura propoziției și deplasarea verbului. Bucharest: Bucharest University Publishing House.

Ogle, R. (1981). Redefining the scope of root transformations. Linguistics, 19, 119-146. https://doi.org/10.1515/ling.1981.19.1-2.119

Pană Dindelegan, G., \& Maiden, M. (Eds.). (2013). The Grammar of Romanian. Oxford: Oxford University Press.

Poole, G. (2007). Interpolation and the Left Periphery in Old Spanish. M. Hussein, M. Kolokante, \& C. Wright (Eds.), Newcastle Working Papers in Linguistics 13 (pp. 188216). Newcastle upon Tyne, United Kingdom: School of English Literature, Language and Linguistics, University of Newcastle.

Prince, E. (1981). Towards a taxonomy of given-new information. P. Cole (Ed.) Radical pragmatics (pp. 223-256). New York: Academic Press.

Reinhart, T. (1982). Pragmatics and Linguistics: An Analysis of Sentence Topics. Bloomington, Indiana: Indiana University Linguistics Club.

Reinheimer, S., \& Tasmowski, L. (2005). Pratique des langues romanes. II. Les pronoms personels. Paris: L’Hartamann. 
Renzi, L., \& Andreose, A. (2003). Manuale di linguistica e filologia romanza. Bologna: Il Mulino.

Renzi, L., Salvi, G., \& Cardinaletti, A. (2001). Grande grammatica Italiana di consultazione. Rome: Il Mulino.

Rochemont, M. S. (1986). Focus on Generative Grammar. Studies in Generative Linguistic Analysis 4. Amsterdam: John Benjamins. https://doi.org/10.1075/sigla.4

Shaer, B. (2009). German and English left-peripheral elements and the 'orphan' analysis of nonintegration. B. Shaer, P. Cook, W. Frey, \& C. Maienborn (Eds.), Dislocated Elements in Discourse. Syntactic, Semantic, and Pragmatic Perspectives (pp. 366-397). New York: Routledge. https://doi.org/10.4324/9780203929247

Sornicolà, R. (1994). On word-order variability: A case study from a corpus of Italian. Lingua e Stile, 29, 25-57.

Vallduví, E. (1992). The Informational Component. New York: Garland.

van Putten, S. (2014), Left dislocation and subordination in Avatime (Kwa). R. van Gijn, J. Hammond, D. Matić, S. van Putten \& A. V. Galucio (Eds.), Information Structure and Reference Tracking in Complex Sentences (71-72). Amsterdam/Philadelphia: John Benjamins Publishing Company. https://doi.org/10.1075/tsl.105.03van

Winkler, S. (2012). The information structure of English. M. Krifka, \& R. Musan (Eds.), The Expression of Information Structure (pp.71-94). Berlin/Boston: Walter de Gruyter. https://doi.org/10.1515/9783110261608.71

Zubizarreta, M. L. (1998). Prosody, focus, and word order. Cambridge, MA: MIT Press. 